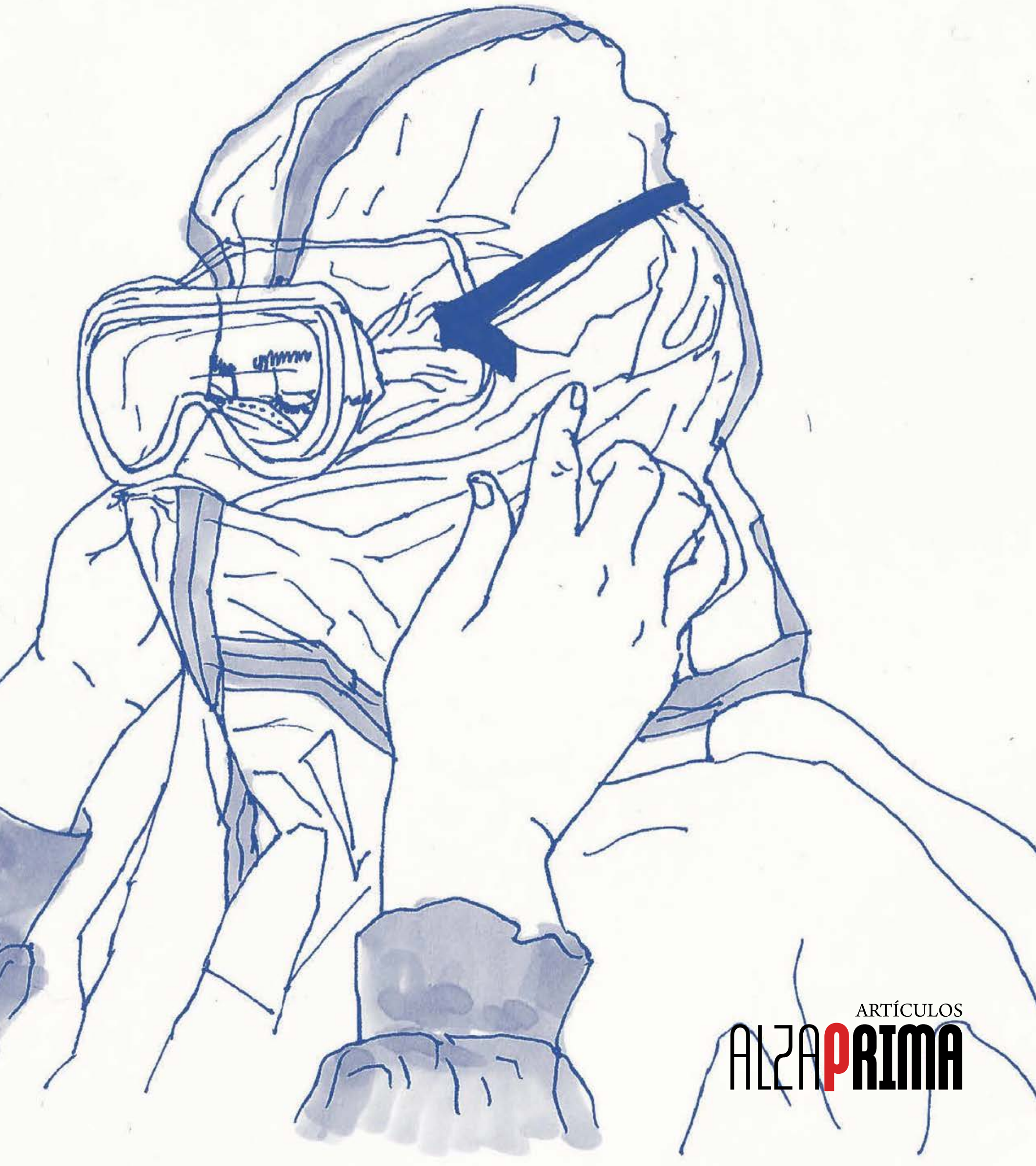




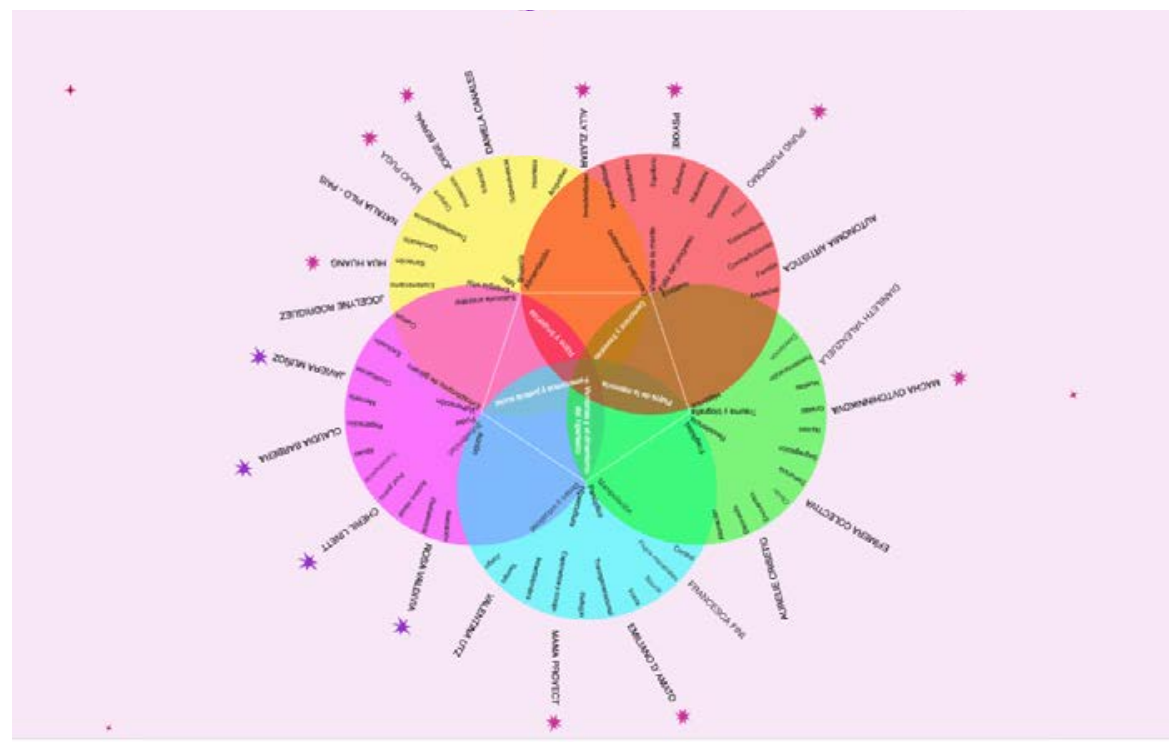




\section{REPARACIONES CIRCULARES O THE LONG GAME OF PATIENCE RESTORATIVE CIRCLES OR THE LONG GAME OF PATIENCE}

\section{Loreto González Barra (Chile)}

Licenciada en Trabajo Social y curadora independiente.

Nancy Mansilla Alvarado (Chile)

Licenciada en Artes y Educación, Magíster en Psicología Social, mención en intervención psicosocial y evaluación de proyectos sociales. colectivainternacionalista@gmail.com

https://colectivainternacionalista.hotglue.me/

https://doi.org/10.29393/AP13-1RCNL20001

\section{Resumen}

El texto responde a una práctica teórica realizada durante la primera etapa de cuarentena producto de la pandemia de COVID-19, la cual busca replantear las modalidades de trabajo en el área de las artes visuales y afines, a nivel glocal. Este proyecto se trata de operaciones cartográficas en donde una diversidad de trabajos vinculados a distintos temas curatoriales, que se rigen en torno al pensamiento afectivo, crítico y ecológico, se reúnen y cruzan, mediante el hipertexto y la intersección, para expresar creativa y pedagógicamente un sin fin de voces que revelan la importancia de presentar las heridas coloniales que tan urgentes son de reparar para la memoria histórica de la humanidad. En ese sentido, la retaguardia y la mutualidad son concepciones fundamentales dentro del campo de acción para alzarnos socialmente como comunidades y con ello hacer valer otras narrativas que se escapan de la hegemonía del saber, en tanto la circularidad y la paciencia son las formas en que construimos temporalmente una fuente inagotable de colaboraciones dispuestas a enfrentar las diversas crisis que nos afectan transversalmente.

Palabras clave: Reparaciones circulares, hipertexto, mutualidad, intersección, alzamiento.

\begin{abstract}
The text deals with a theoretical practice carried out during the first quarantine stage as a result of the COVID-19 pandemic, which sought to reconsider working conditions in the visual arts and other related areas, at a glocal level. The project works on cartographic operations where different projects in connection to diverse curatorial themes, working around affective, critical and ecological thinking, come together through hypertext and intersection, to creatively and pedagogically express numerous voices that reveal the importance of manifesting the colonial wounds that must be urgently addressed in order to restore humanity's historical memory. In this sense, rearguard and mutuality are fundamental concepts within the field of action to rise up socially as communities, and thereby enforce other narratives that escape the hegemony of knowledge, while circularity and patience are the ways in which we temporarily build an inexhaustible source of collaborations to face the various crises that affect us across the board.
\end{abstract}

Key words: Restorative circles, hypertext, mutuality, intersection, uprising 
Una atmósfera siniestra envuelve el planeta. El aire

del ambiente, saturado de las partículas tóxicas del régimen colonial-capitalístico, nos sofoca. [...] ejerce su seducción perversa sobre el deseo cada vez más violento y refinadamente, llevándolo a entregarse aún más gozosamente al abuso. En este grado de expropiación de la vida, una señal de alarma se dispara en las subjetividades: la pulsión se pone entonces en movimiento y el deseo es convocado a actuar. Y cuando se logra tomar las riendas de la pulsión, tiende a irrumpir un trabajo colectivo de pensamiento-creación que, materializado en acciones, busca hacer que la vida persevere y obtenga un nuevo equilibrio. Por eso, los momentos como este que estamos viviendo siempre son los más vigorosos e inolvidables

(Rolnik, 2019, pp. 21-25).

Ante la certeza de navegar en una atemporalidad de tránsitos inhóspitos, a través de umbrales de paso y transmutación, y con la convicción que hoy más que nunca necesitamos acercarnos afectiva y políticamente para sobrellevar las contradicciones a las que nos ha empujado el actual alzamiento social y que además ha desnudado el COVID-19, es que como curadoras independientes, más la colaboración de nuestros respectivos centros de operaciones La Pan ${ }^{1}$ (Valparaíso) y CAPUT ${ }^{2}$ (Iquique), hemos creado una conexión de retaguardia ${ }^{3}$, descentrada y disímil con el objetivo de construir una plataforma experimental para la permanente investigación sobre artes y visualidades, hoy desde el hipertexto.

Esta búsqueda se acerca a un plan de trabajo curatorial activista $^{4}$ que viaja por una dimensión dispersa. Para comprenderse a sí mismo recorre marcos interpretativos a modo de horizontes, cargados de confluencias e intersecciones en espiral, ecosistemas por descubrir a medida que vamos explorando, creando y produciendo para el crecimiento de un tejido rizomático constelado entre mujeres y disidencias del universo artístico y a manera de tramar una red sólida que nos permita, en plena crisis, apoyarnos mutuamente para sobrellevar/ transitar por los turbulentos tiempos que traen consigo las formas soterradas de las estructuras de poder. Se trata de un soporte de contención y acción que

1. https://www.lapangaleria.com/, https://lapan.hotglue.me/

2. https://caput.hotglue.me/

3. Una que esté al otro lado de la vanguardia discursiva y proclame el fin del arte contemporáneo, como señala Iván de la Nuez: "ante la imposibilidad de amalgamarse con la vida, consiga al menos una fusión fructífera con la supervivencia” (De la Nuez, s/f, p. 11).

4. Sus principales acciones están siendo organizadas y visualizadas en https://colectivainternacionalista.hotglue.me/ 
nos invita, bajo una política imaginaria, a reparar(nos) de manera circular y colectiva queriendo traspasar cualquier tipo de orden establecido que nos sujete a la cosmovisión del capital, especialmente la que nos somete a una lógica geográfica irrumpida por las fronteras territoriales. Por lo mismo, la intención de amplificar aquella visión se concreta desde un llamado internacionalista como una nueva cartografía social y política.

Situar la curaduría como un campo de probabilidades ha implicado abordarla desde la idea de reciprocidad y elaboración recompositiva de los afectos, del cuidado mutuo y la necesidad de hacer lenguaje los signos que establecen nuevas relaciones entre los discursos, los contextos y las prácticas. En ese sentido, un primer posicionamiento surge del hacernos parte de acciones situadas en la micropolítica intersectada del cuerpo físico y virtual, donde jugamos con textos, imágenes, audiovisualidades e hipervinculaciones varias que aportan al modo en que algunas identidades nos constituimos en espacios de pensamiento y acción alternativos para subvertir marcos ideológicos, culturas y prácticas monolíticas y homogeneizantes que, como consecuencia de la estrategia de dominación del proyecto civilizatorio moderno y posmoderno, jerarquizan el valor como estrategia de dominación, anulando las diferencias.

Pero, ¿cuánto podemos hacer al respecto?, ¿hasta dónde podemos llegar? Para respondernos ha sido necesario situarnos al borde de la cerca que nos limita, atravesar sus márgenes y hacer presión desde nuestro campo de acción cotidiano. Levantar acciones concretas, individuales y conjuntas que hagan vivo el deseo por componer, preparar y reparar(se) en colectivo. Lo que implica perforar cajas: los cubos físicos y cuadrados virtuales que encierran el problema.

Reparaciones Circulares emerge desde las propias cuerpas a través de los feminismos en colectividades de confianzas y resistencias instaladas, y avanza hacia todo proyecto de emancipación que obligue a salir de este oscuro tiempo. Nos desprendemos de los cánones tradicionales de temporalidad, normalidad y normatividad y con ello, nuevamente, propagamos esporas para la fertilización de alianzas dispuestas a atraer y producir otres ecosistemas, por ahora principalmente desde la virtualidad. Pensándolo igualmente como una cuerpa en disputa que nos permite encontrar a través de propuestas lúcidas, señalamientos que reviertan los alarmantes e inciertos planos del eterno retorno. Nos nombramos así, desde una pluralidad radical, feminista y transformadora como Colectiva internacionalista. 


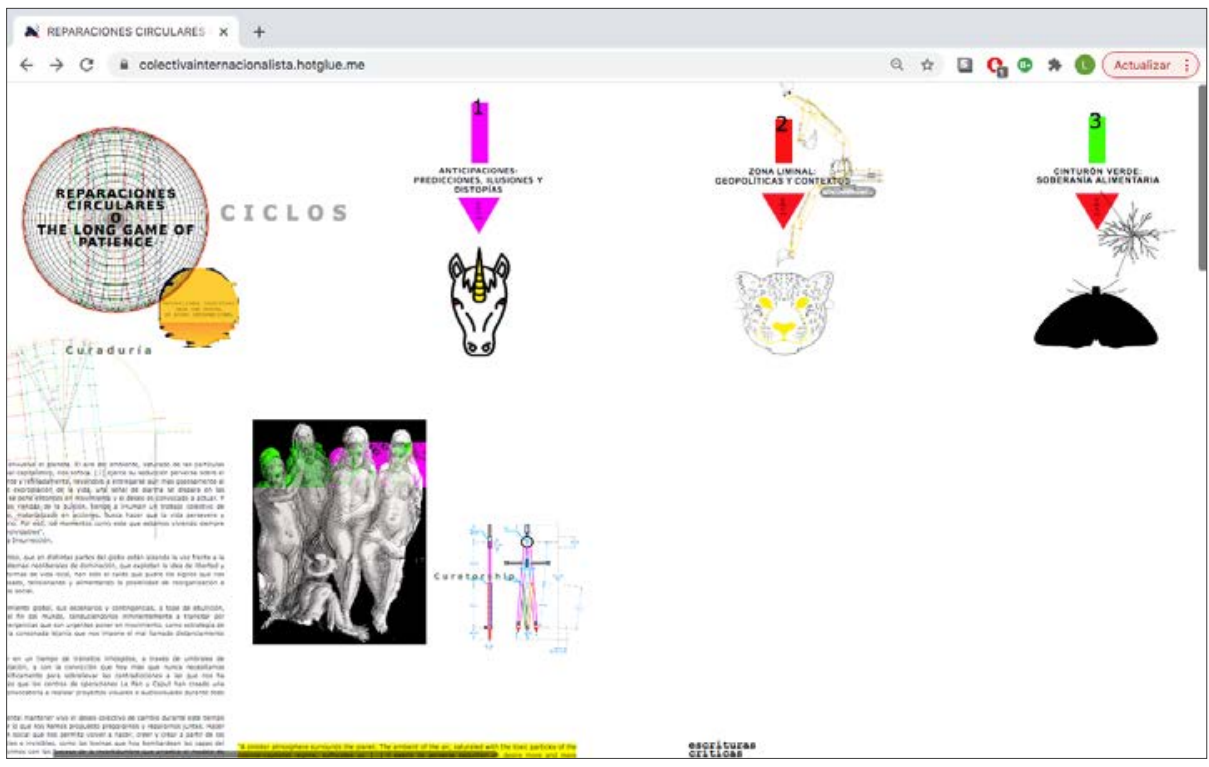

Fig. nº1: Fragmento de la portada del sitio web de reparaciones circulares.

\section{Virtualidad vs Realidad: colonialismos ${ }^{5}$ y neocolonialismos}

Este enunciado trae consigo dos conflictos biopolíticos basales vinculados a las nociones de justicia social y de reconocimiento (Butler y Fraser, 2017; Rorty, 1996; Honneth, 2010; Ricoeur, 2006) y que hasta hoy constituyen un dilema en curso, al que hacemos un guiño a través de la reflexión de Montserrat Garcelan cuando se pregunta, "¿de qué nos vale una política de reconocimiento de [...] y de la pareja dignidad de todas ellas si no va acompañada de un análisis de sus dimensiones económicas y del lugar que esa discriminación ocupa en el sistema económico en su conjunto?” (Butler y Fraser, 2017, p. 13). Son tantas las desigualdades estructurales y micro desigualdades cotidianas con las que podemos completar el espacio que dejamos en [...], que nos parece por lo menos preocupante, considerando, además, que por lo general estas no apuntan a formas de acción e interacción colectiva alejadas del sistema neoliberal, ni a la promoción de intersecciones situadas entre discriminaciones, sino que compartimentan como si unas no tuvieran que ver con otras, banalizando y marginando lo distinto. Una tecnología compleja que perpetúa las desigualdades.

Sabemos que

el capitalismo debe justificar y mistificar las contradicciones incrustadas en sus relaciones sociales -la promesa de libertad frente a la realidad de la coacción generalizada- denigrando la naturaleza de aquellos a quienes explota: mujeres, súbditos coloniales, descendientes de esclavos africanos, inmigrantes desplazados por la globalización (Federici, 2017, p. 36).

\footnotetext{
5. Para efectos de este escrito los debates entre colonialismo y neocolonialismo se desprenden de la noción de colonialidad del poder de Aníbal Quijano (1992) y sus derivados, donde identifica y caracteriza el fenómeno de estructuración del poder que se inicia con el descubrimiento de América y que, hasta el día de hoy, continúa en expansión, haciéndose global y constitutivo del modo en que vivimos y reproduciéndose en las formas de relación social a través de cuatro dimensiones entrelazadas: raza, división social del trabajo, organización social del poder, estado - nación y hegemonía eurocentrista, donde la dominación, la explotación y el conflicto generan un patrón de interacción múltiple que afecta a toda la existencia humana (Quijano, 2014).
} 
Se trata de procesos de acumulación originaria a escala local y global que nos imparten categorías de poder biologicistas y sociales que apuntamos a subvertir, al situar Reparaciones Circulares en un campo de descolonización de la conciencia propia y del colonialismo interno (Cusicanqui, 2010, p. 63) que cada cual arrastra, sus dimensiones temporales, entrecruzamientos y disrupciones discursivas.

Constantemente nos preguntamos ¿cómo ponernos en el punto de vista de otres?, y cuando esto no ocurre ¿cómo abordamos la dimensión ética de la violencia que banaliza lo que no le toca?; y finalmente ¿cómo estas jerarquías se perpetúan en los circuitos de arte? Si bien aún debemos recorrer un largo trecho, decidimos que la base de la curaduría misma se planteara como un trayecto multidimensional en sintonía fina con quienes se identifican como mujeres y disidencias para generar una red de apoyo mutuo.

La mutualidad desde los bordes descentrados en los que nos situamos responde a una serie de prácticas individuales y colaborativas que a lo largo de los años han ido cimentando micropolíticas de lo cotidiano en los espacios que compartimos desde La Pan y CAPUT.

Desde luego, los sentidos de mundo basados en la acción mutual con que actualmente algunos circuitos viven en camino hacia la redefinición del arte, contienen dinámicas estrechamente vinculadas a la práctica doméstica del diario vivir, pero que junto con ellas apuntan a la construcción de dinámicas de investigación procesuales, experimentales $y$ muchas veces lentas, basadas en profundizar y generar relaciones virtuosas (más que en producir resultados rápidos o simplemente instalarse en el tema de moda), fundamentales para proyectar pensares, sus sensaciones, funciones e ideas de verdad. Además, es importante considerar que hoy más que nunca -al encontrarnos eminentemente confinadas- somos atravesadas por el universo hipertextual, lugar en el que corremos el riesgo de transformarnos en "una especie de ser-ventana, que constaría de ventanas a través de las cuales concebiría el mundo" (Han, 2018, p. 68), transitando espacios simbólicos que hacen habitable la coexistencia en el contexto actual, pero que corren el riesgo de estandarizar las formas de producción colectiva. Por otro lado, es también una oportunidad: ¿qué es la realidad virtual sino lo que cada cual construye y cree de ella? 
Esta pregunta activa la responsabilidad de habitar lo distinto ${ }^{6}$, un modo de ocupación y de repensar cómo resituar estructuras de poder y realidades paralelas dentro de un dispositivo web, para hacer de esta la proyección de un pensamiento colectivo horizontal y no jerárquico, que soporte una diversidad de derivas a través de ejes o tranvías que desplazan información proveniente de distintas partes del globo ${ }^{7}$. Al fin y al cabo, realidades que acompañan distintos procesos de creación según la forma de ver e interpretar el mundo de cada persona, y luego, de producción de pensamiento y acción.

Es ahí donde la transformación o el desplazamiento bidireccional del mapa de posiciones diagrama un espaciocuerpo social que acarrea el riesgo de interponer un nuevo paisaje neocolonial, casi inherente al campo de fuerzas antropocéntrico y la conquista del tiempo-espacio, pero también, el borde desde donde se sitúa el flotante nodo de Reparaciones Circulares que busca dislocar, a través de la espiralidad, el esquema normado.

Vemos necesario y urgente revisar los ejercicios mediales como un campo de batalla a disputar, evitando la definición de conocimientos con un enfoque categórico, y analizando los ecosistemas creativos e intelectuales para impulsarlos hacia lo inmenso. Lo anterior es vital, considerando que la cuestión del (re)colonialismo (Quijano, 1992, p. 11), en todas sus dimensiones, opera como una estrategia muteada que sostiene e incuba restricciones y codificaciones sustentables montadas como muros que pueden llegar al paroxismo, e impiden conocer y nadar en otras profundidades.

La fricción entre virtualidad y realismo versus colonialismo y neocolonialismo no es más que un roce cuántico dentro del espacio exterior. Son relaciones dispares que tienden a enfrentarse y muchas veces a adaptarse entre ellas y que necesitamos comprender sin alejarnos de los retos del presente, "hoy tenemos pocas restricciones de acceso al conocimiento, pero sí muchos mecanismos de neutralización de la crítica. Entre muchos otros podemos destacar cuatro: la saturación de la atención, la segmentación de públicos, la estandarización de los lenguajes y la hegemonía del solucionismo" (Garcés, 2020, p. 49). Entonces, la unión entre idea y sensación, entre pensamiento y emoción, y entre cuerpo y espacio, nos llevan a insistir, como señala Mario Pedrosa, en un arte experimental como ejercicio de libertad (Jara, 2013) que siendo universal y recíproco vincule y haga uso de nuestros saberes para redefinir los sentidos de la emancipación

6. Lo distinto como efímero y cada vez más fugaz al ser rápidamente identificado por la maquinaria neoliberal que absorbe toda idea y concepto, cooptándola para sus propios fines, banalizándola.

7. Desde una geolocalización transfronteriza que supere los rígidos emblemas de los desarrollos industriales anunciados por el proyecto moderno. Construimos una cartografía aludiendo a los lugares de referencia desde donde se ubican las artistas participantes, más no de donde nacen sino desde donde pertenecen. Visitar en: https://www. google.com/maps/d/u/1/edit?mid=1ynWaXR2VA2_WfsT2vjGWQA7qvwuxViID\&ll=0.10833099717164174\%2C0\& $\mathrm{z}=2$ 
(Garcés, 2020). Hoy debemos vivir con un virus que no conocemos ni podemos ver, que nos sabemos si es real o virtual, un veneno en el aire que se introduce en nuestros interiores, pero que no puede infectar lo más profundo de nuestros posicionamientos, saberes y prácticas.

No podemos dejar la revolución en manos del virus. Confiemos en que tras el virus venga una revolución humana. Somos nosotros, personas dotadas de razón, quienes tenemos que repensar y restringir radicalmente el capitalismo destructivo, y también nuestra ilimitada y destructiva movilidad, para salvarnos a nosotros, para salvar el clima y nuestro bello planeta (Han, 2020, párr. 21).

\section{Ejercicios de activismo curatorial}

Como señala Le Guin (2017), plantear la curaduría desde un escenario altamente probable, es decir, como un campo expandido que permite transitar por diversas áreas, es introducirse en la imaginación como supervivencia. Los procesos que han emergido del curar Reparaciones Circulares lo hacen desde un rápido repensar las propias prácticas en el contexto de la pandemia mundial. Como relata la crítica de artes visuales Victoria Ramírez (2020):

La muestra fue lanzada desde una interfaz web mientras el brote de Covid-19 estaba en plena ebullición y las primeras consecuencias tanto a nivel político como socio-cultural y económico de la pandemia comenzaban a hacerse notar. Por un lado, un gran sector del circuito artístico se encontraba incapaz de operar con normalidad a nivel mundial y se encontró de frente con su propia ineptitud para adaptarse a los recursos virtuales que se le presentaban como oportunidad (párr. 7).

Nos hicimos parte de la crisis ocupándonos de sostener nuestra propia autonomía del saber, desarrollando lo que De Kerckhove llama, "una nueva superficie que invita a crear transiciones y por ende, relaciones, entre un espectador (antes) pasivo y un público participativo activo, mediante la popularización masiva de las tecnologías y en conexión con el imaginario de las aplicaciones de realidad virtual" (2010, p. 2). Y es que los cambios de un estado físico a uno particularmente inmaterial, son aparentemente una transformación en sí misma, donde el intercambio tradicional de signos pierde potencia como conjunto de prácticas e interpretaciones vinculadas principalmente a la mirada historiográfica del arte. Comienza a ejercerse otra fuerza, distinta, que nace de un proceso ultra dinámico y compuesto por un abundante flujo de modos y estilos como base de una interconexión de ingenios, experiencias y conocimientos, entre artistas y no artistas. Una experiencia performática que permite leerlos como múltiple representación.

Las artes del internet y la tecnología han sido abordadas en esta curaduría a una escala doméstica. Vamos aprendiendo del mundo digital, mientras somos diseñadoras web, amigas, curadoras, mediadoras, productoras, gestoras y un largo etcétera que se redefine cada cierto tiempo desde el diálogo, la intuición, lo afectivo-cotidiano y lo micropolítico. 
Reparaciones Circulares o the long game of patience se mueve en esta malla ${ }^{8}$ enjambre de interconexiones ${ }^{9}$ a través de nodos de relaciones móviles y vivas desde donde emergen desclasificaciones en forma de imágenes y diagramas de investigación, textos, mapas de redes e hipervínculos. Estos han sido pensados desde un germen under y de open source que nos impulsa a volver a una interfaz algo noventera de estética retro-futurista cargada de elementos como el glitch, ruidos molestos, bloques de color y gifs animados.

Integrar tal diversidad promueve interconexiones que nos permiten observar, experimentar, posicionarnos y comprender aciertos, errores, temores y desasosiegos, y adaptarnos en este aparente limbo en el que nos encontramos; una suma de aprendizajes surgidos de procesos individuales y colectivos, en los que trabajamos desde la acción directa y la obra, a partir del desarrollo de pedagogías experimentales y metodologías colaborativas centradas en la horizontalidad, la reciprocidad y mutualidad, la producción de investigación basada en las artes y el desarrollo del pensamiento crítico como práctica política. Cada llamamiento es abierto a quien quiera participar, los grados de participación son diversos y van desde la colaboración implicándose en un ciclo completo, por ejemplo, en procesos de investigación situada que derivan en dispositivos estéticos o de mediación; desde una participación creativa en el desarrollo de contenidos y posicionamientos en cada ciclo; o la simbólica, que ha sido fundamental para afinar sintonías; incluso la participación nominal, que nos va dando el pulso desde aquello que se constituye como lo común.

Asimismo, su cultura disidente, feminista y provinciana, con énfasis en la multitud y mixtura de lenguajes - que hacen del proyecto una cuestión política y, por cierto, irruptiva y embrollada- no es más que la oportunidad para desplazar, desde lo digital, pensamientos y acciones que establecen diálogos entre la hipertextualidad y la colaboración y que hacen este ejercicio sostenible a lo largo del tiempo. Desde este meta lugar, es importante hacer de la curaduría una producción agitable y discontinua utilizando el dentro y fuera de la pantalla como excusa para accionar el presente del espacio social, inventando otros bordes para acercarnos a la proyección de un nuevo universo de acciones de emancipación y autonomía.

Es fundamental, como ya hace años manifestara Gabriela Mistral, vivir la mutualidad como fuente de saber feminista, y lo internacional como espacio para la reivindicación de la pelea por una humanidad más humana (Del Pozo, 2015). Hacer de esta una práctica recíproca en medio del desastre, es un respiro colectivo que se expande de las fronteras geográficas -y políticas-, permitiéndonos pensar(nos) como una torre de babel con un mismo cuerpo y un mismo territorio ${ }^{10}$.

8. Utilizando el término utilizado por Timothy Morton (2018): "la malla se refiere a los agujeros de una red y a los hilos que la forman. Sugiere tanto fortaleza como delicadeza. Se usa en biología, matemáticas, ingeniería, tejeduría e informática: medidas y diseño gráfico, metales, tejidos. ... se relaciona con máscara y masa, lo que sugiere tanto la densidad como el engaño. Por extensión, malla significa una situación compleja o una serie de hechos en los que una persona se ve envuelta, una concatenación de fuerzas o circunstancias restrictivas; una trampa" (p. 48). 9. En referencia a la idea de B. Fuller, acuñada por Alexia Tala (2018) en la revista Terremoto. $\mathrm{mx}$, sobre arte y libertad: introducción a una geopoética institucional.

10. En referencia con la idea-expresión de Silvia Rivera Cusicanqui (2015) en el auditorio Roberto Carri de la Facultad de Sociología de la UBA, Buenos. Aires, Argentina: "Estoy en contra de la metáfora falocéntrica y cristiana de la torre de Babel porque en ella la diversidad lingüística es pensada como castigo. Esta pluralidad se debe a que la tierra necesita muchas lenguas para decirse y no una maldición de un Dios cristiano que se enojó con los hombres”. 
Nos situamos, entonces, en lo que hemos llamado una retaguardia radical, algo así como una arquitectura de la crisis que no se somete a una condición póstuma ${ }^{11}$, sino más bien, se hace cargo de producir y visibilizar conocimiento colectivo emancipatorio desde lo sobrevivido, lo sobrevivible y lo que está por sobrevivirse, y lo hace desde la provincia, alejada de los centros de pensamiento y poder geopolíticos y mercantilizantes del arte, tejiendo de manera fortuita a medida que la colaboración recíproca con diversidad de otres agentes se hace cuerpo en cada iniciativa de esta curaduría que es activista y además es lenta o un slow curating.

No podemos seguir en una actitud nostálgico -defensiva que sólo busque prolongar cómo vivíamos antes de la pandemia, sino que "necesitamos elaborar el sentido de la temporalidad: más que promesas y horizontes utópicos, relaciones significativas entre lo vivido y lo vivible, entre lo que ha pasado, lo que se ha perdido y lo que está por hacer [...] (Garcés, 2020, p. 74).

\section{Acerca de las crisis y las producciones desde un alzamiento radical feminista}

Habrá que superar el multiculturalismo oficial que nos recluye y estereotipa, pero también dar la vuelta al logocentrismo machista que dibuja mapas y establece pertenencias. La noción de identidad de las mujeres se asemeja al tejido. Lejos de establecer la propiedad y la jurisdicción de la autoridad de la nación - o pueblo, o autonomía indígena- la práctica femenina teje la trama de la intraculturalidad a través de sus prácticas: como productora, comerciante, tejedora, ritualista, creadora de lenguajes y símbolos capaces de seducir al "otro" y establecer pactos de reciprocidad y convivencia entre diferentes $[. .$. (Cusicanqui, 2010, p. 72).

En menos de una estación de tiempo, el año 2020 trajo consigo producciones en arte y cultura desde medios digitales. La posibilidad del website y las múltiples interconexiones que convergen en la nube ha dado espacio a la circulación de todo tipo de teorías, metodologías y estrategias, como las de carácter colaborativo e independiente.

Reparaciones Circulares invita a interactuar con una cartografía polifónica, que como sistema de interpretación situada es eminentemente cognitiva. Produce y da giros experimentales a partir de lugares de paso, porosidades que transitan por procesos de investigación intersticiales entre lo curatorial y lo pedagógico, configurando canales de comunicación a través de tópicos vinculados a contextos y percepciones sobre el largo juego de la paciencia que compromete el futuro y los haceres que lo construyen.

Durante el año 2020, Reparaciones Circulares confeccionó tres cuerpos de obra, organizados en tres ciclos curatoriales o fases, desde mayo de 2020 hasta principios de 2021. Partiendo con Anticipaciones. Ilusiones, Predicciones y Distopías; luego en agosto con Zona Liminal. Geopoliticas y Contextos; y en diciembre con Cinturón Verde. Soberanía Alimentaria. Cada una ha ampliado las rotaciones conceptuales del campo artístico, convocando a la diversidad como fuente de producción crítica e intercambio de conocimientos.

11. La cual Marina Garcés (2020), plantea como la irreversible destrucción de nuestros modos de vida, por lo que no someterse a ella vendría a ser la principal tarea del pensamiento crítico emancipatorio. 


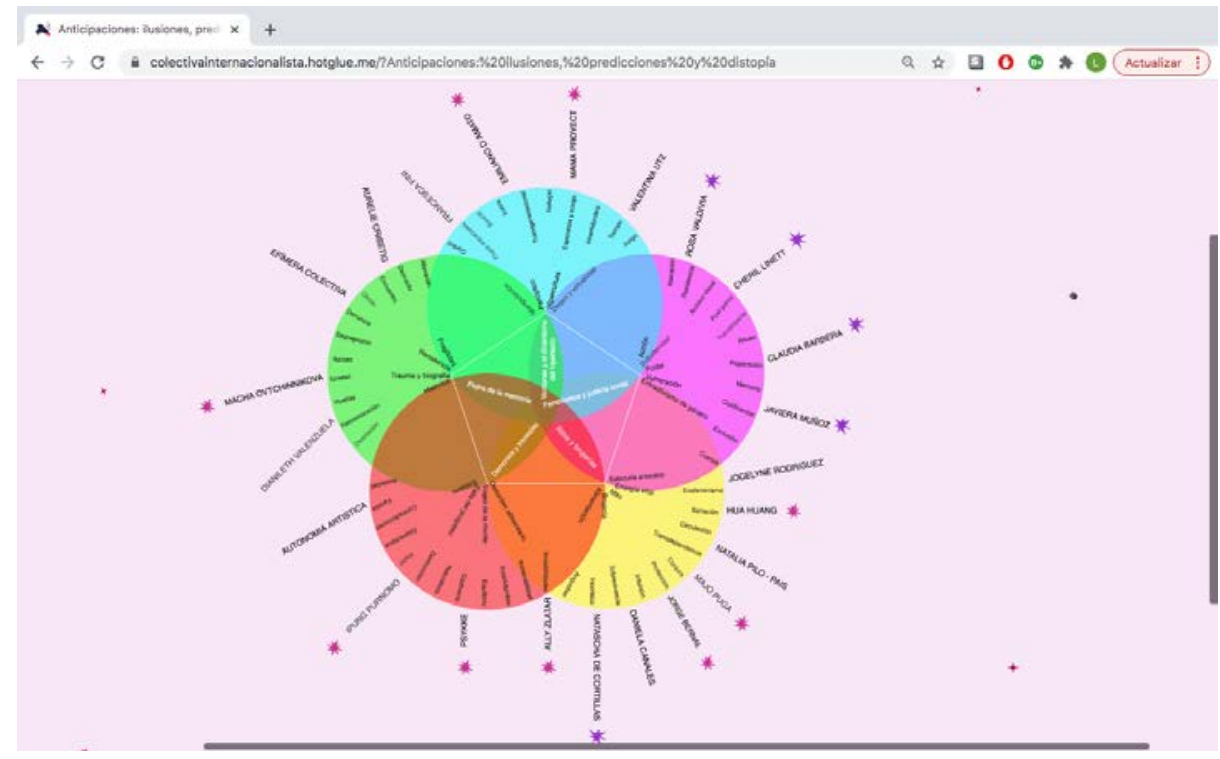

Fig. n²: Diagrama de ejes conceptuales vinculados a artistas participantes según organización de trabajos para la curaduría $\mathrm{n}^{\circ}$ 1: Anticipaciones. Predicciones, Ilusiones y distopías. El esquema se sitúa como referencia del cruce entre la rosa cromática, que aporta la diversidad y las transformaciones del color, con la viabilidad de la rueda o lo circular, que es capaz de girar y/o combinar.

Para Anticipaciones. Ilusiones, Predicciones y Distopías ${ }^{12}$, la investigación se centró en las formas en que nos relacionamos con otres hoy, las que en gran medida acontecen a partir de una llamada por teléfono o la virtualidad de una pantalla, y esta última, a veces funciona como bisagra permitiéndonos interactuar bidireccionalmente con otro ser vivo; otras veces nos lleva a un viaje laberíntico a través del click, "tiene una abertura hacia afuera, pero al mismo tiempo nos protege del mundo. Como una especie de ventana, la pantalla surte un efecto no sólo revelador, sino también protector" (Han, 2018). Pero ¿hasta qué punto realmente esa bisagra revela y protege, cuando hoy más que nunca los poderes fácticos operan desde una política de control y vigilancia del comportamiento atópico? ¿Qué nuevas políticas sensibles establecen nuestras cuerpas con el medio y cómo podemos generar nichos de libertad, protección y resistencia?

¿De qué arquitectura de la crisis podemos hacernos cargo en estas condiciones? ¿Qué nos atrevemos a anticipar desde la homogeneizante idea de progreso? o ¿hasta cuándo se sostienen las predicciones? Estos son algunos de los cuestionamientos que comprometen a una comunidad interesada en perturbar, señalar y conjurar, mediante distópicas fantasías ${ }^{13}, \operatorname{ritos}^{14}$, resistencias y sus grietas $^{15}$, a las relaciones de dominio y dependencia entramadas en las formas de $\operatorname{poder}^{16} \mathrm{y}$ sus consecuencias para los viajes de cada mente ${ }^{17}$. Tal como presenta la artista italiana Francesca Fini ${ }^{18}$ en su trabajo "Confinamento", en

12. Algunos de los principales conceptos abordados son los siguientes: fragilidad, resistencia, trauma y biografía, historia, manipulación, panóptico, hipercultura, deseo y virtualidad, acción, subalternidad, poder, vulneración, extractivismo de género, sabiduría ancestral, energía vital, mito, brujería, alimentación, desorden alimentario, viajes de la mente, falla del progreso, encierro. Visitar en https://colectivainternacionalista.hotglue.me/?Anticipaciones:\%20ilusiones, $\% 20$ predicciones\%20y\%20distop\%C3\%ADa

13. Registro pictórico de una performance de ensueño. Emiliano D’amato en el eje Ventanas y el Dinamismo del Hipertexto.

14. The Gua Sha, Treatment Pop. Hua Huang en el eje Ritos y Brujerías.

15. The Scar of the Earth. Macha Ovtchinnikova en el eje Flujos de la Memoria.

16. Comunicado/Yeguada latinoamericana. Cherril Linett en el eje Feminismos y Justicia Social. 17. The Temple of 10,000 demons. Psykke en el eje Demonios y Travesías.

18. Para más información, visitar https://colectivainternacionalista.hotglue.me/?francesca+fini 
donde se toma de dispositivos de vigilancia de principales espacios turísticos del país durante la cuarentena de 2019, los cuales mostraban una surrealista y distópica imagen de estas ciudades ahora desiertas y silenciosas producto del confinamiento en pandemia. La artista roba la señal de la webcam y transmite a través de un software que registra y rastrea el escaso movimiento, transformándolo en flujos de datos que sintetiza y luego retransmite a través de Facebook Live, poniendo a disposición de la ciudadanía la panóptica transmisión.

Reparaciones Circulares es un trabajo que nos anima a "reimaginar nuestro mundo como si fuera ordenado por un deseo colectivo de igualdad radical" (Butler, 2020. párr. 5). Es decir, a repensar el espacio como un lugar de ex(com)posición plural y crítica, divergente, capaz de activarse y sostenerse mediante herramientas que aporten a que diferentes personas cuestionen las relaciones de producción de las fuerzas productivas que están contenidas en su espacio social (Lefebvre, 2013), y re-escriban nuevas formas de coexistencia en base a sus propias interpretaciones.

Recibir y hacer emerger este tipo de propósitos aviva una sincronicidad premonitoria, desobediente, hereje y ocultista, de espíritu e ingenio decidido, que responde con fuerza y creación a un llamamiento que es individual pero también colectivo, $\mathrm{y}$ que ruge a mantener las llamas encendidas de quienes presagian en colectividad e igualdad, las posibilidades del cosmos como espacio trascendental.

Estas prácticas de protección son parte de la propuesta de Majo Puga ${ }^{19}$, en palabras de la autora, parten del "autocuidado, la escucha y el deseo" ${ }^{20}$. El juego y la ritualidad se hacen parte de operaciones que transitan entre el arte y la pedagogía, desde la investigación autoral a ser parte de una serie de ejercicios de mediación -en curso- que utilizan el arte correo como medio táctico y establecen relaciones rizomáticas y descentradas con el hipertexto mestizo y sus ventanas de posibilidades, algo así como una estrategia de red que entra y sale de la virtualidad hacia un viaje experimental buscando espacios de encuentros físicos.

Durante cada ciclo, nos ha parecido esencial tramar las mediaciones de un proyecto curatorial que es prácticamente afectivo, desde espacios que generen cruces amplios y se movilicen como una red de lazos a modo de zonas de contactos, donde se pierdan las fronteras entre arte y pedagogía en cada ejercicio, quedando interconectados los saberes y las tecnologías, en tanto traducción de conocimientos como también núcleo de experiencias.

19. Para más información, visitar https://colectivainternacionalista.hotglue.me/?Majo\%20Puga/

20. Extraído del Instagram de Majo. Publicación del 3 de agosto. 


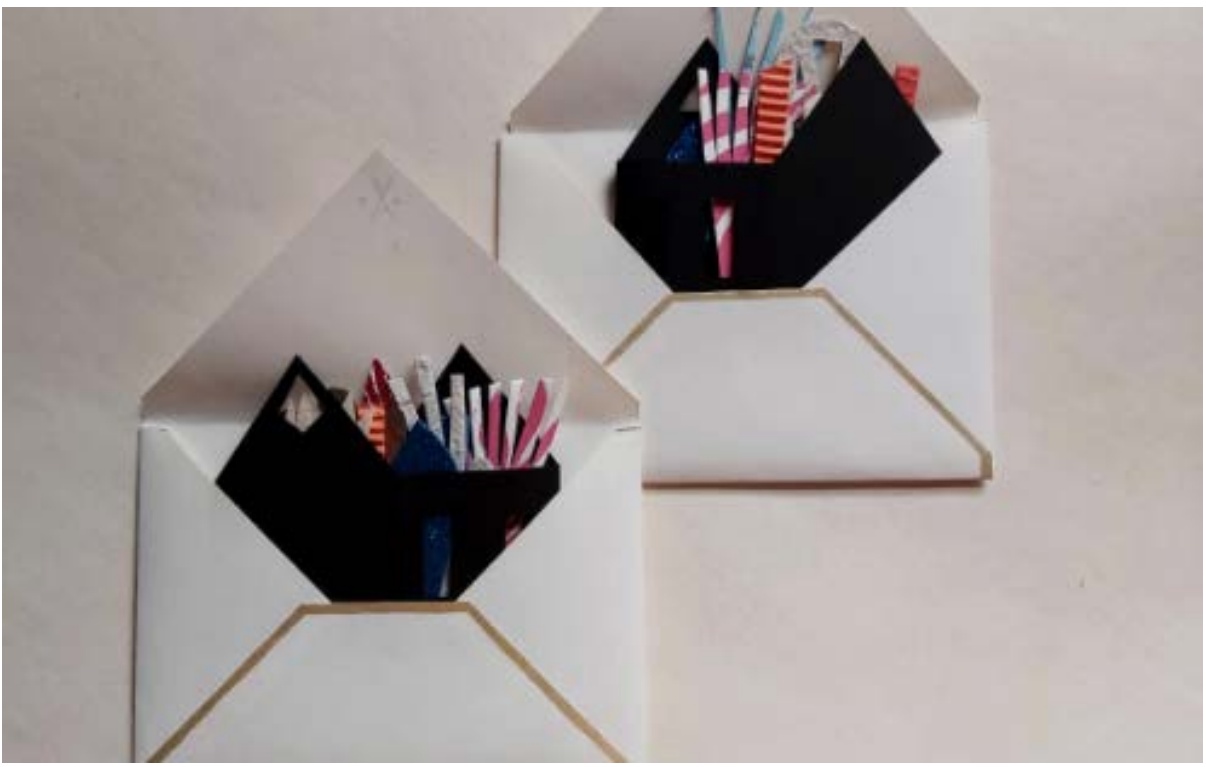

Fig. n³: Plantas de poca luz es un ejercicio de mediación de Majo Puga para la curaduría $n^{\circ} 1$, el cual implica un proceso de reciprocidad mediante la corriente del arte correo. En este plan de trabajo, la artista juega e interactúa con personas desconocidas mediante el espacio físico y digital, transitando por la templanza y la protección.

Luego, para cuestionar y confrontar las ideas de 'realidad' y 'verdad' y desde una catástrofe interna en efervescencia, saturada de inquietudes y profecías, surge Zona Liminal ${ }^{21}$ : Geografías y Contextos ${ }^{22}$. En este segundo ciclo posicionamos la ambigüedad del jaguar como expresión suprema de las fuerzas de la tierra ${ }^{23}$, bien sea desde la naturaleza o interpretada desde la superioridad nacional de países cuya herencia es el capitalismo salvaje.

Aquellas fuerzas antagónicas están en tensión constante dentro de la interfaz de Reparaciones Circulares, constituyéndose en una sólida bestia con múltiples brazos que acoge a una humanidad interpelada por las promesas no cumplidas de la modernidad - representada en el modulor maquinizado y transmutado en una jaguar- y las amenazas de una era distorsionada y póstuma. Entonces, cartografiamos nuevos alfabetos de posibilidades que articularon mallas de producción de subjetividad situadas entre la greca y el píxel, entre los lenguajes de la imagen, el mapa de bit y las distorsionadas nociones de verdad, y entre lo que pensamos, lo que decimos y lo que hacemos.

21. Lo liminal entendido como el estado intermedio y ambiguo en los ritos de paso (Van Gennep, 1969). Las llamadas gentes de umbral, se encuentran en el paso mismo por lo que no están ni en un estado ni en el otro, por lo que son ambiguos y desposeídos, por ejemplo, los eclipses, encontrarse en el útero (Turner, 1988) o el paso por la muerte (ver concepto de umbral al inicio de este texto según Han, 2017). Como ritos de transformación, los umbrales requieren mucho tiempo por lo que incorporan y escenifican corporalmente (Han, 2020).

22. Algunos de los principales conceptos abordados son los siguientes: política, intersticio social, protesta, cuerpos y fronteras, transgresión, habitar el límite, estallido social, opresión, género, coexistencia, justicia social, espacio de fuga, patriarcado, resignificación, pudrición, desconfianza, migración, etnografía del cuerpo, permanecer, memoria cartográfica, herencia cultural, extractivismo, espiritualidad, poder, especismo, interseccionalidad, violencia, necropolítica, nación. Visitar en https://colectivainternacionalista.hotglue.me/?zona+liminal1

23. "En el Abya Yala y según su origen, el jaguar simboliza entre otros, a las diosas luna- tierra, a las brujas, a las montañas, al eco y al cielo, pero por sobre todo, es la expresión suprema de las fuerzas de la tierra, como en los mitos brasileños donde aparece como el guardián del fuego. Pero el Jaguar, es también utilizado para calificar a este país llamado Chile, el supuesto "jaguar de América Latina”, populismo extractivista utilizado en un esfuerzo por comparar su también supuesta y hoy desmitificada fuerza económica con "el tigre asiático"”. Extracto del texto que reflexiona sobre este ciclo. Disponible en: https://colectivainternacionalista.hotglue.me/?zona+liminal1 


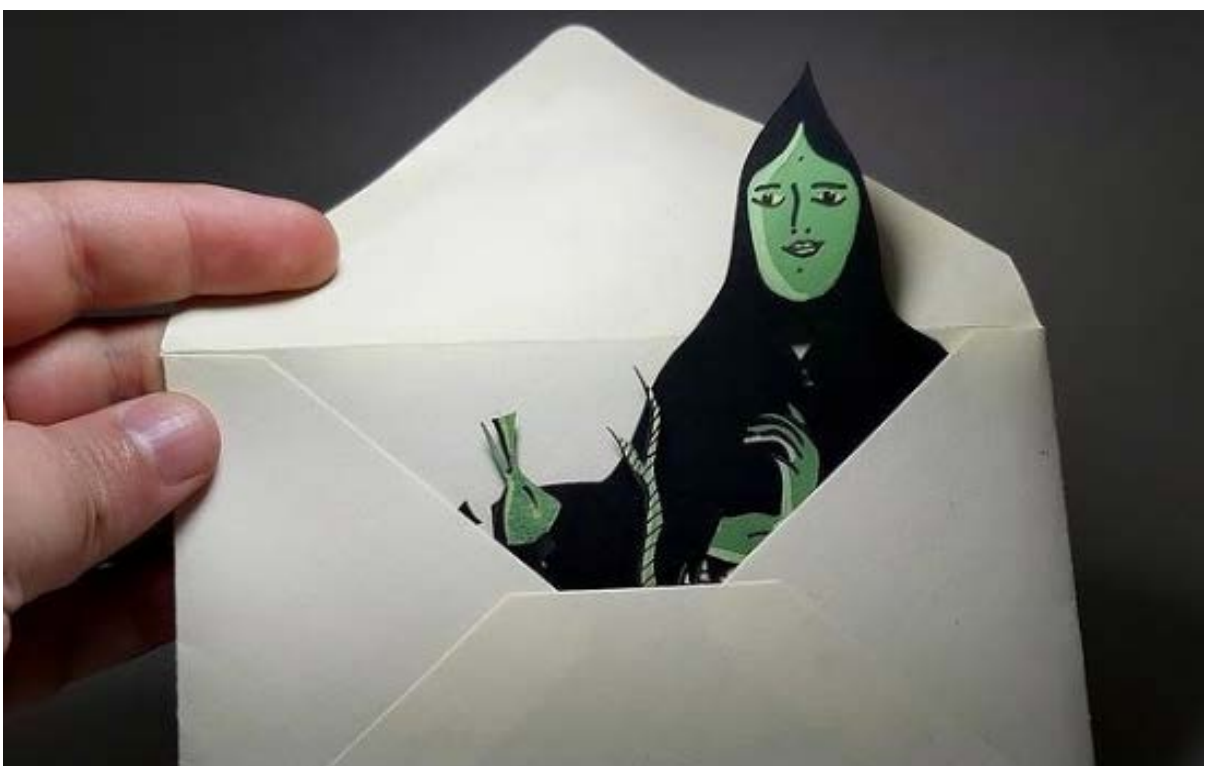

Fig. n4: "Plantas de poca luz" es un ejercicio de mediación de Majo Puga para la curaduría nº1, el cual implica un proceso de reciprocidad mediante la corriente del arte correo. En este plan de trabajo, la artista juega e interactúa con personas desconocidas mediante el espacio físico y digital, transitando por la templanza y la protección.

Sin embargo, a pesar de las insostenibles violencias ancladas en las ideas de nación y sus consecuentes políticas psicosociales ${ }^{24}$, la compasión neoliberal se compete así misma en la medida que refuerza sus propios valores y psiquis intersectadas a favor de la cultura occidental ${ }^{25}$. $\mathrm{Al}$ respecto, nos preguntamos: ¿qué bordes transitamos para que otros espacios sociales nos lleven a romper con los efectos de un pensamiento colonial, lineal, histórico y agresivamente unidireccional $?^{26}$

Es precisamente en esta esfera de relaciones de configuración espacio -temporal que las formas de sometimiento han de friccionar-como las placas tectónicas bajo nuestros pies -para producir lo que según Judith Butler es un

rise up against something - they know that they wish to overthrow, what condition they seek to bring to and end. Their action has an aim: they are seeking freedom and self-determination, dignity, mobility justice, or equality. In standing, they are getting ready to act and to free themselves from shackles that have been shouldered for too long $^{27}$ (Didi-Huberman, 2016, p. 24).

Resolver las inquietudes y malestares sociales mediante la liberación de fuerzas subterráneas resignifica- disidentemente la oferta cultural y económica del patriarcado ${ }^{28}$.

24. 00:01:22:YO: ROTACIÓN. Julio Urbina en el eje De venenos y Necropolíticas.

25. Simulación Espiritual. Bruno Borgna en el eje Erosiones.

26. Eje Tránsitos y Bordes. Visitar en: https://colectivainternacionalista.hotglue.me/?ZONA+LIMINAL

27. Una de las decisiones que tomamos desde el primer ciclo, es que mantendremos los textos o en el idioma original o en el idioma de preferencia de cada artista, como estrategia de democratización para el uso diverso de las diferentes lenguas. Lo anterior, a propósito de que llegaron trabajos de artistas provenientes de distintas partes del globo, pero también, de que muchos textos de referencia no están traducidos o simplemente el sentido de los mismos cambia - profunda o levemente- en cada traducción, también porque hemos decidido formar parte de la torre de babel que es capaz de contener y diseminar la diversidad y riqueza lingüística.

28. Desplazamiento, Plan de Contención. Coral Revueltas / Re(bi)siones. Angelo Álvarez en el eje Montañas del deseo. 


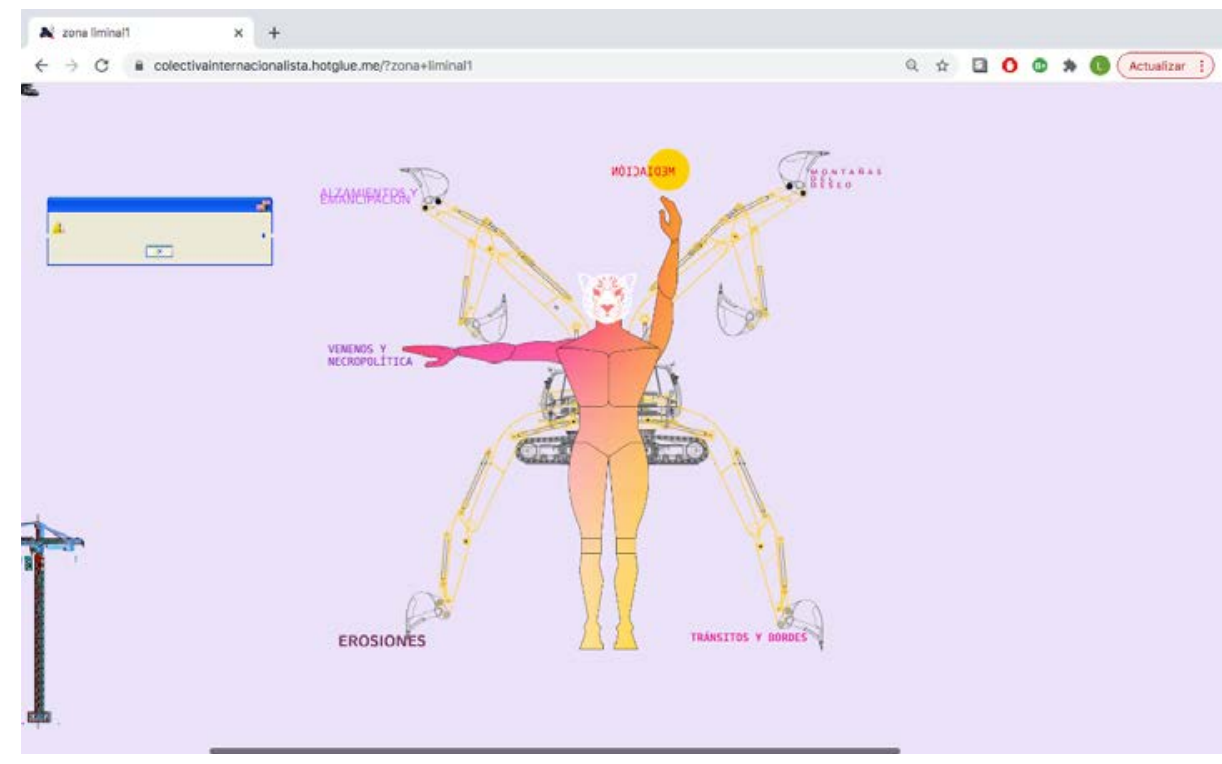

Fig. $n^{\circ} 5$ : Diagrama de ejes conceptuales señalizados mediante brazos que organizan los trabajos presentados en la curaduría n²: Zona Liminal. Geopolíticas y Contextos. El esqueleto hace relación entre las extremidades que componen el cuerpo humano más el desarrollo industrial a través de su maquinaria, conformando un organismo vivo en constante contradicción.

Aparecen los alzamientos sociales, coexisten las manifestaciones y protestas en contra de una insolente clase política y una hegemónica minoría de titiriteros del mundo. Se repara la multitud en un solo cuerpo mutante que corre desde las señales de sumisión a los gestos de emancipación, rearmándose colectivamente para atravesar el intersticio social ${ }^{29}$. Como señala Byung Chul Han, "el umbral es el tránsito a lo desconocido ... Por eso el umbral siempre lleva inscrita la muerte. En todos los ritos de paso, los rites de passage, se muere para renacer más allá del umbral. La muerte se experimenta aquí como transición. Quien traspasa el umbral se somete a una transformación" (2017, p. 57), una que sepa reubicar las dimensiones del poder (común), ya que es en estos espacios de la diferencia donde están siempre abiertas las posibilidades de resistencia y transformación.

En esta lógica, el grupo de activación VIRUS $\operatorname{TDS}^{30}$ utiliza la idea de infección para intervenir el sitio web de esta curaduría, movilizando nuevas formas de articulación entre las distintas capas de conexión que existen entre artistas y sus trabajos. En su sitio web ${ }^{31}$ se señalan como "a network of affective and political contagion for the resistance against the productive and reproductive neoliberal system and its deployment of precarised and instrumentalised art and culture" (VirusTDS, párr. 1). Una manera de desarrollar interdependencias y transversalidades desde la posibilidad del contagio digital y la creación de una red virtual que se enrede con la idea de reciprocidad, situándose en la liminalidad de la praxis medial como un estado de apertura (en el pensar pedagógico) que designa nuevos lenguajes de producción y comunicación a partir del cuerpo y de todo deseo.

29. Peinture-Vaudou. Stephane Billot en el eje Alzamientos y emancipaciones.

30. Técnicas des'generadas de subsistencia. Visitar en https://virustds.hotglue.me/

31. Visitar en: https://virustds.hotglue.me/?reparacionescircularesthelonggameofpatience/ 


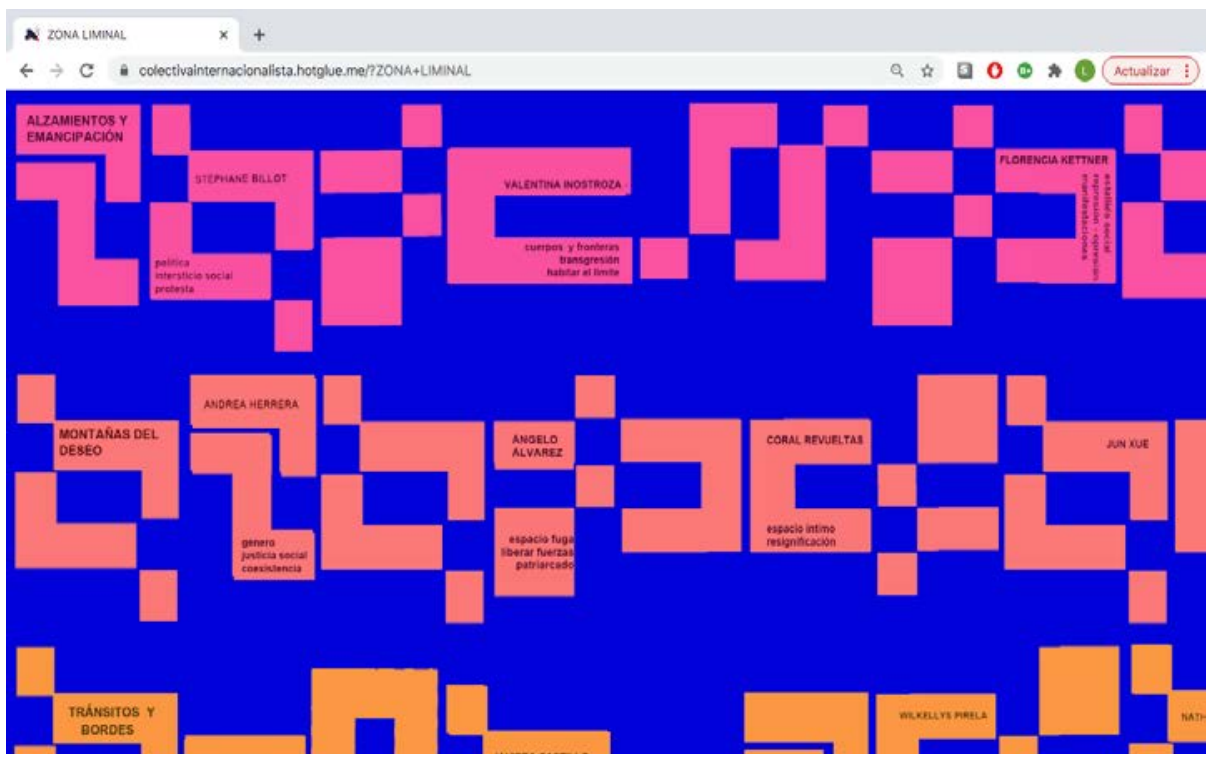

Fig. n6: Mapa de piezas que funciona como capas de presentación de las artistas y sus trabajos participantes en la curaduría $\mathrm{n}^{\circ} 2$. El mapa corresponde a la fusión entre los pixeles del bit y las geometrías de la greca, confeccionando una contemporánea narrativa visual en sí misma.

En este lugar, se sumergen los vaticinios del extractivismo y se escuchan o se hacen oídos sordos- las insistencias de la tierra, en un nuevo campo de batalla sobre la verdad de las cosas. Es aquí, en el Cinturón Verde: Soberanía Alimentaria ${ }^{32}$, tercer ciclo de Reparaciones Circulares, donde apostamos por un pensamiento ecológico entendido como

[...] el análisis de la interconectividad ... una reflexión sobre la ecología, pero también una forma ecológica de pensar ... Es una práctica y un proceso que consiste en llegar a ser plenamente conscientes de que los seres humanos están conectados con otros seres: animales, vegetales o minerales. En definitiva ese poder nos lleva a pensar en la democracia. ¿Cómo sería un encuentro realmente democrático entre seres realmente iguales? ¿acaso podemos imaginarlo? (Morton, 2018, p. 24).

Un pasaje deslocalizado que reanima la insurrecta dificultad de responder a ideales en discordia. Una práctica anticolonial que no gesta ni categoriza el ecosistema, sino que lo comprende desde la colectividadyla corresponsabilidad, tal cual como funciona un panal en su colmena, en mutualidad de todos sus habitantes. En este sistema, es fundamental el rol de las polinizadoras, como obreras de la naturaleza, dispuestas a diseminar la vida y actuar en el presente para un futuro conjunto.

32. Algunos de los principales conceptos abordados son los siguientes: micropolítica - organización- doméstico- cotidianeidad - producción local- ruralidad- herencia- agricultura- agroecología- nutrición- salud- derechos- política agraria- medio ambiente- diversidadcultivo- ecofeminismo- autonomía. Visitar en https://colectivainternacionalista.hotglue. me/?cinturonverde 
Esto pareciera ser un trance en medio de sensaciones excéntricas, no obstante se trata del vínculo más profundo, atemporal e infinito entre seres, tierras y territorios. En el caso de las ciudades, pareciera ser que viven de una ilusión, necesitan de otros para sobrevivir, pero existen como si sólo se bastaran a sí mismas,

food comes from outside of cities for the overwhelming majority of people (only $1 / 5$ of food is produced in cities globally). Energy sources are harvest or produced far away. Housing materials travel long distances to get cities, The oxygen we breathe is primarily generated by algae in seas, which can be adjacent to or near, but are not regularly integrated into, cities" (Bloom, Clausen, Fortune \& Sonjasdotter, 2016, p. 15).

No podemos seguir por el camino aparentemente fácil, sino que es necesario cuestionar la seguridad alimentaria que ofrece el mercado y construir interdependencia, creando corredores de conexión e intercambio entre áreas fragmentadas y con posibilidades de reciprocidad positiva. En definitiva, debemos crear otras formas de coexistencia para el buen vivir en un paradigma civilizatorio no capitalista (Cusicanqui, 2010), ya que la circulación de la vida es fundamental.

En ese sentido, es fundamental hacer de las intensidades cotidianas un factor micropolítico que incorpore esporas y brotes a contrapelo de lo 'fragmentado', que descascare los relatos y los descomponga para hacer de ello un refugio de recuperación de los paisajes del subconsciente ${ }^{33}$ y, también, una estrategia para relevar los símbolos de resistencia alimentaria, como la investigación de Sebastián Calfuqueo (2020) sobre los hongos:

los hongos son una fuente de alimentación muy importante para las comunidades Mapuche. Este saber ha persistido, en algunas comunidades que han transmitido su conocimiento de generación en generación, técnicas para recolectarlos correctamente, sin dañar el micelio para que siga fructificando, con respeto al otro, sin infligir daño alguno (parr. 1) $)^{34}$.

Una potente práctica de cuidado y responsabilidad con los ecosistemas, que es también un dispositivo pedagógico decolonial.

Teniendo en cuenta estas alteridades, en un ambiente donde todo pudiera manipularse, se hace insistente el profundizar en las fortalezas de una corporalidad híbrida que intenta modificarse desde el hambre, el ruido y deseo ${ }^{35}$.

33. Artistas, Melissa Ferreira y Florencia Marinetti.

34. Artista Sebastián Calfuqueo, obra Mapu Kufüll (mariscos terrestres).

35. Privater Salat. Nicol Rivera ft Juvenal Barría en el eje Naturalezas, Saberes y Pervivencias.

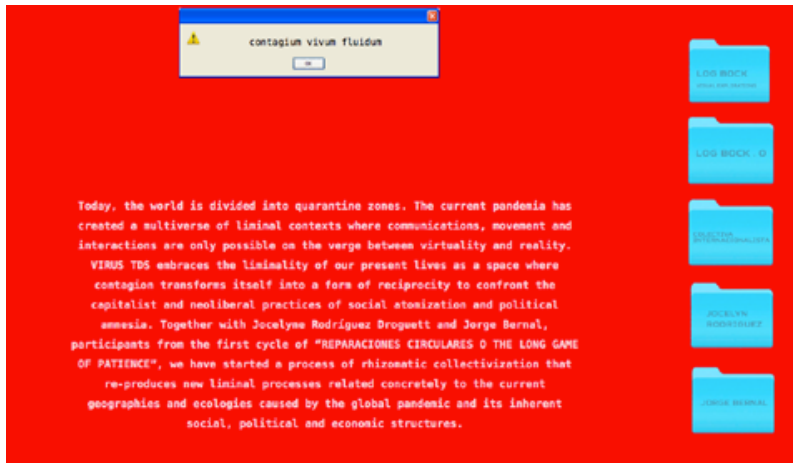

Fig. no7: "Espacio de contagio" es un ejercicio de mediación del colectivo Virus TDS para la curaduría n², el cual busca infectar con energías anticoloniales, tanto a la plataforma como a les demás artistas participantes mediante intervenciones virtuales.
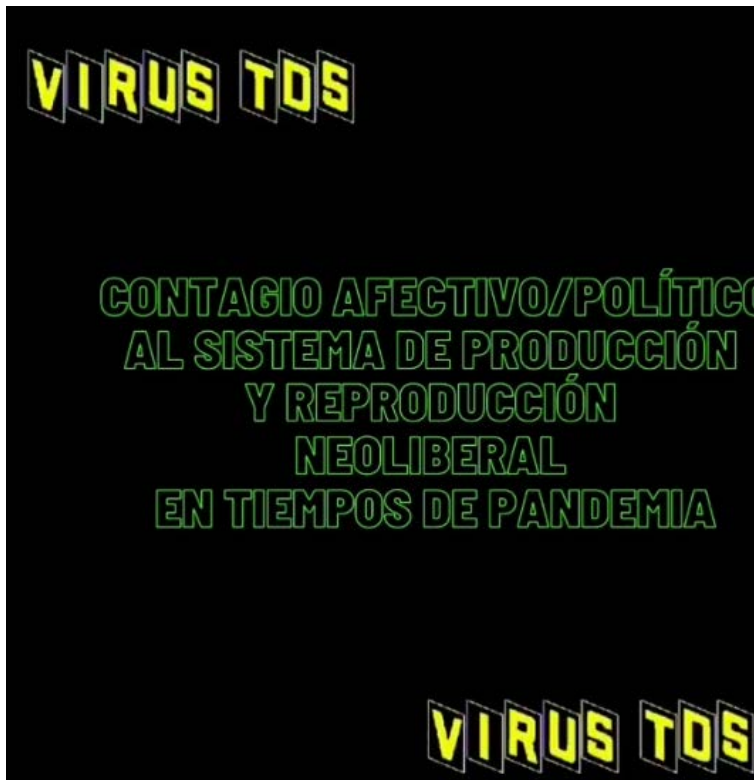

Fig. no8: "Espacio de contagio" es un ejercicio de mediación del colectivo Virus TDS para la curaduría $\mathrm{n}^{\circ} 2$, el cual busca infectar con energías anticoloniales, tanto a la plataforma como a les demás artistas participantes mediante intervenciones virtuales. 


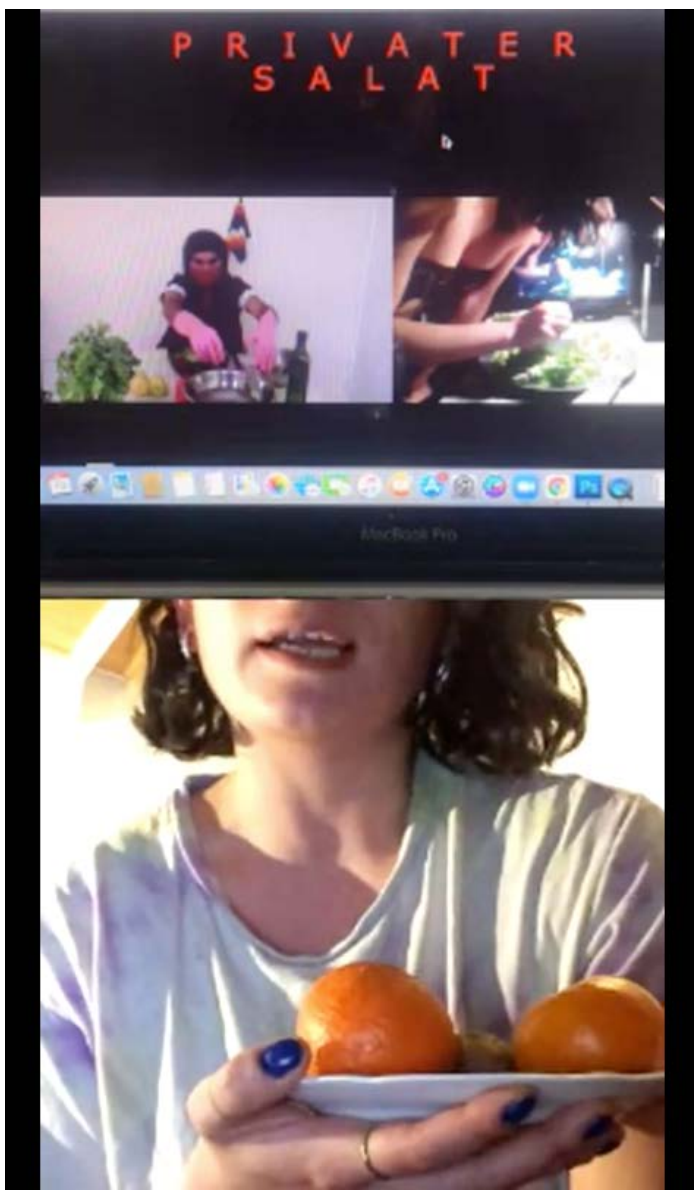

Fig. no9: Privater salat una obra de Nicol Rivera en colaboración con Juvenal Barría para la curaduria número 3, la cual indaga en cómo los contextos modifican las relaciones de todo orden.
Un tejido que no resiste más la emergencia del hambre e instala la carencia, la ansiedad y la ausencia como un factor subjetivo de la vida. Una ruleta de muchos sacrificios y pocos privilegios dispuestos a considerarse si se hacen imprescindibles para amortiguar las frustraciones ${ }^{36}$.

A pesar de que llegamos tarde, debemos atender a las reconceptualizaciones que instan a actuar de manera distinta, llamando a un nuevo posicionamiento, donde todes seamos parte de la diversidad de la cadena de procesos alimentarios -de la tierra a la mesa- a largo plazo. Para que dejemos de lado la producción industrial, basada en el mercado capitalista y nacionalista que, a partir de la globalización de las redes de mercado, ha implicado un alto costo para la vida del planeta.

En este tercer ciclo, intentaremos avanzar hacia otro futuro, uno donde sistemas ecológicos coexistan con cinturones verdes, extensos cordones biológicos y ecosistemas bióticos. Pues, asegurar la vida de todos los ecosistemas es también parte del cuidado mutuo que debemos redescubrir, por lo que es importante que dejemos de excluir a Gaia de sus derechos, tal como plantea Leonardo Boff cuando señala, a propósito de comprender la Ciudadanía de la floresta:

después dehaber creadola amenaza dela destrucción de la Tierra - Gaia, no podemos excluirla del nuevo pacto social, como lo hicieron Hobbes, Rosseau y Kant. Ellos daban por descontado el futuro de la tierra. Hoy ya no es así. Devastada Gaia, no hay más base para ningún tipo de ciudadanía. Si queremos sobrevivir juntxs, la democracia tiene que ser también biocracia y cosmocracia $(2015$, p. 5$)$.

Entonces, desde nuestra micropolítica intersectada se hace fundamental accionar también desde los procesos en arte + pedagogía, que implican ciertos $e \cos ^{37}$ en donde repensemos las formas en que vivimos y se levanten curas $\mathrm{y}$ remedios que cultiven el buen vivir, y que nos hagan cuestionarnos respecto de cuánto sabemos del lugar dónde vivimos ${ }^{38}$.
36. Caldo de caja de ayuda gubernamental. Vania Caro en el eje $\mathrm{Nu}$ dos del hambre.

37. Procesos de mediación para Cinturón Verde. Visitar en https:// colectivainternacionalista.hotglue.me/?ECOS/

38. Durante el ciclo de Cinturón verde: soberanía alimentaria, se levantará a través del Ig de Reparaciones circulares el Quiz biorregional, una herramienta pedagógica que desde 1981 invita a cuestionar si conocemos el lugar dónde vivimos. Este quiz ha generado un gran impacto para pensar cómo las biorregiones se van adaptando a contextos específicos. 


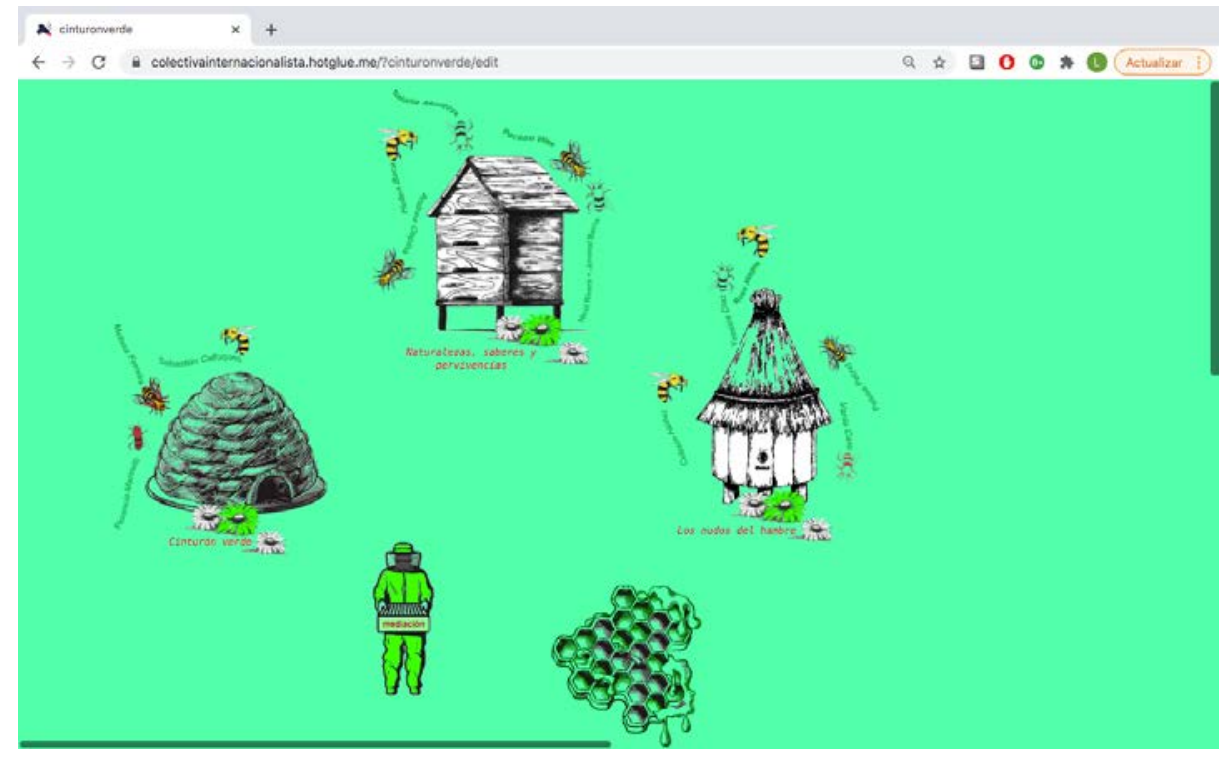

Fig. n¹0. Plantas de poca luz es un ejercicio de mediación de Majo Puga para la curaduría no1, el cual implica un proceso de reciprocidad mediante la corriente del arte correo. En este plan de trabajo, la artista juega e interactúa con personas desconocidas mediante el espacio físico y digital, transitando por la templanza y la protección.

Finalmente, y a modo de cierre, esperamos como Colectiva internacionalista aportar desde una retaguardia radical feminista a la construcción colectiva de conocimiento situado que diversifique las voces de quienes quieren expresarse, y que desde ahí indague y profundice en las distintas dimensiones del trabajo colaborativo que transita entre proceso y resultado, entre arte y pedagogía, y que al mismo tiempo, pudiera ser todas y ninguna de ellas. Un ejercicio de reparación circular que avanza en espiral, que no se encierra en sí mismo sino que se conecta con otres, y que nace y muere a partir de cada umbral que atraviesa para aprender juntes cómo coexistir y sobrevivir desde la resistencia más allá de las geografías, las entonaciones y los múltiples lenguajes por cohabitar en medio de espacios de hospitalidad (curatorial) en el transgredido ámbito digital.

\section{Referencias bibliográficas}

Boff, L(2015). Florestanía. FLORAE \#1, 4-5.

Bloom, V., Clausen, M, Fortine, B \& Sonjasdotter, A. (2016). Food Futures. Conversations about the future of food and agriculture in the Berlin-Branderburg bioregion. Berlin: The Neighborhood Academy.

Butler, J. y Fraser, N. (2017). ¿Reconocimiento o redistribución? Un debate entre marxismo y feminismo. Madrid: Traficantes de sueños.

Butler, J. (2020). Capitalism Has its Limits. Verso. Recuperado de: https:// www.versobooks.com/blogs/4603-capitalism-has-its-limits.

Calfuqueo, S. (2020). Mapu Kufüll (mariscos de tierra (hongos)). Reparaciones circulares. Cinturón verde soberanía alimentaria. Recuperado de: https:// colectivainternacionalista.hotglue.me/?Sebastian+Calfuqueo

Cusicanqui, S. (2010). Ch'ixinakax Utxiwa. Una reflexión sobre prácticas y discursos descolonizadores. Buenos Aires: Tinta Limón. 
De Kerckhove, D. (2010). Avatar= Pinocho 2.0 o $\ll$ El fin de la sociedad del espectáculo». Digithum, (12). Recuperado de: http://openaccess.uoc.edu/ webapps/o2/bitstream/10609/8800/2/n12-de-la-digitalizacion-de-lacultura-a-la-cultura-digital.pdf

Del Pozo, D. (2015). Por la humanidad futura. Antología política de Gabriela Mistral. Santiago: Editorial La Pollera.

Didi-Huberman, G. (2016). Uprisings. París: Editions Gallimard /Jeu de Paume.

Federici, S. (2017). Caliban y la bruja. Mujeres, cuerpo y acumulación originaria. Madrid: Traficantes de sueños.

Garcés, M. (2020). Nueva ilustración radical. Barcelona: Anagrama.

Han, B. Ch. (2018). Hiperculturalidad. Cultura y globalización. Barcelona: Herder.

Han, B. Ch. (2017). La expulsión de lo distinto. Barcelona: Herder.

Han, B. Ch. (2020). La emergencia viral y el mundo de mañana. Byung-Chul Han, el filósofo surcoreano que piensa desde Berlín. El País. Recuperado de:https://elpais.com/ideas/2020-03-21/la-emergencia-viral-y-el-mundo-demanana-byung-chul-han-el-filosofo-surcoreano-que-piensa-desde-berlin.html.

Honneth, A. (2010). Reconocimiento y menosprecio. Sobre la fundamentación relativa de una teoría social. Buenos Aires: Katz editores.

Jara, N. (2013). El arte como ejercicio experimental de la libertad. MSSA, Coloquio: Educar para transformar. Santiago, Chile.

Le Guin, U. (2017). Contar es escuchar. España: Círculo de Tiza.

Lefebvre, H. (2013). La producción del espacio. Madrid: Capitán Swing.

Morton, T. (2018). El pensamiento ecológico. Barcelona: Paidós.

Quijano, A. (1992). Colonialidad y Modernidad/Racionalidad. Ed. Perú Indígena.

Quijano, A. (2014). Cuestiones y horizontes: de la dependencia históricoestructural a la colonialidad/descolonialidad del poder / Aníbal Quijano; selección a cargo de Danilo Assis Clímaco; con prólogo de Danilo Assis Clímaco. - 1a ed. - Ciudad Autónoma de Buenos Aires: CLACSO.

Ramírez, V. (2020). Lo que podemos en los límites: Reflexiones sobre el ciclo expositivo "Zona Liminal: Geopolíticas y Contextos" (Texto inédito, escrito en diciembre de 2020).

Ricoeur, P. (2006). Caminos del reconocimiento. Tres estudios. México D.F.: Fondo de Cultura Económica.

Rolnik. S. (2019). Esferas de la Insurrección. Apuntes para descolonizar el inconsciente. Buenos Aires: Tinta Limón.

Rorty, R. (1996). Objetividad, relativismo y verdad: escritos filosóficos I. Barcelona: Paidós.

Virus TDS (2020). Entrevista de Virus TDS a Colectiva internacionalista. Reparaciones Circulares. Recuperado de: https://colectivainternacionalista. hotglue.me/ 